\title{
In This Issue
}

An article by NANCY J. SMITH-HEFNER examines the social history of the adoption of a standard variety of the Javanese language in a culturally nonstandard area of East Java. In other times and other places, high Javanese kromo was used as a vehicle for expressing politeness. In the modern Tengger region, however, it has been used as an instrument for asserting the Javaneseness of the people who speak it, at a time when broad political changes have been undermining more traditional appeals to local solidarity.

In the most popular North Indian version of the Rãm legend, the sixteenth-century Hindi epic Rämcaritmānas of Tulsīdās, a multivocal narrative of interwoven dialogues is linked together by the powerful allegory of a Himalayan lake and its four encompassing banks. PHILIP LuTGendorf draws on the insights of the epic's traditional commentators and performers to explore the relationship between the epic's framing strategy and the influential genres of exegesis and performance that have developed around it. He suggests that the Hindi poet's graphic allegory symbolically encodes a traditional Indian hermeneutic.

OMKAR GOSWAMI looks at the business history of eastern India in the middle of the twentieth century, when important changes were taking place. He sees these changes as part of a single process in which there are four major components: the decline of British managing agencies, the rise of Marwaris, the rise and fall of Bengali firms, and the growth of multinational corporations.

To understand the pattern of business-state relations in colonial Korea, DeNNIS MCNamara looks at the role of the Keijō Chamber of Commerce and Industry (Keishō). He finds that this organization reinforced the development strategies set forth by the colonial administration and private enterprise. It also acted as a nexus for Korean business ties between state officials and Japanese private enterprise and helped to shape the patterns of postwar business relations.

Bureaucrats in Japan have historically played a predominant political role, but in the last decade both the conception and the reality of their dominance have been challenged. The conceptual challenge has been raised by a group of younger scholars influenced by U.S. empirical research methods. The real challenge has come from an organized and affluent populace reacting to a long-governing conservative party. GARY D. Aluinson reviews six Japanese books and two special issues of a new Japanese journal to describe some recent, contending views of these and other political changes in contemporary Japan. 


\section{The Journal of Asian Studies}

\section{Connecticut College, New London, Connecticut 06320}

Editorial Board. Editor: Thomas R. H. Havens, Connecticut College. Associate Editor: ANDREW J. Nathan, Columbia University. Assistant Editors: China and Inner Asia, Richard P. Madsen, University of California, San Diego; Japan, Helen Hardacre, Princeton University; Korea, LaUrel Kendall, American Museum of Natural History; South Asia, Lawrence A. BABB, Amberst College; Southeast Asia, ClaRK D. NeHER, Nortbern Illinois University. Book Review Editors: China and Inner Asia, Joanna F. Handus SMITH, Fairbank Center, Harvard University, and William A. JosePH, Wellesley College; Japan, ANDREW GORdON, Duke University; Korea, LaUrel Kendall, American Museum of Natural History; South Asia, PAUL GreenOugh, University of lowa; Southeast Asia, ROBert W. HefNer, Boston University.

Editorial Staff. Manuscript Editor: BETSEY SCHEINER, University of California Press. Editorial Assistant: Mary Jo C. Baldwin, Connecticut College. Proofreader: BonNie Dehler, University of California Press.

The Association for Asian Studies, Inc.

1 Lane Hall, The University of Michigan, Ann Arbor, Michigan 48109

Officers of the Association. President: Stanley J. TAmbiah, Harvard University, Vice President: Barbara Stoler Miller, Barnard College. Secretary-Treasurer: L. A. Peter Gosung, University of Michigan.

Board of Directors. President. Vice President. Secretary-Treasurer. Past President: ROBERT J. SMITH, Cornell University. Past-Past President: RhOADs MurpheY, University of Michigan. Journal Editor: Thomas R. H. Havens, Connecticut College. China and Inner Asia Council: LyNN A. Struve, Indiana University. Northeast Asia Council: D. EleANOR Westney, Massachusetts Institute of Technology. South Asia Council: SANDRA P. RoBINSON, Duke University. Southeast Asia Council: ChARues Hirschman, University of Washington. Council of Conferences: Clifton W. PANNell, University of Georgia.

Staff of the Association. Administrative Associate: CAROL M. HANSEN. Comptroller: Caroline HacketT. Journal Advertising and Records Supervisor: Carol J. Kelingos. Membership Secretary: DonNa Ashton. Conference Coordinator: Karen F. Fricke. Receptionist and Office Assistant: WENDY CORRELL. 